\title{
Applications of pyrolysis for carbonaceous wastes in solid waste management - A mini-review
}

\author{
Rushikesh Joshi, Ganesh R. Kale*, Atul N. Vaidya
}

\begin{abstract}
Due to the aggravating problem of solid waste disposal and rising demand of fuels for energy generation, pyrolysis can serve as a promising solution to both these challenges. The majority of the municipal solid wastes are constituted of carbonaceous wastes including biomass. Pyrolysis can be universally applied to all these types of wastes to obtain non-condensable fuel gases, pyrolysis oils and solid coke achieving complete waste disposal. In the present study, a review of pyrolysis with respect to various types of waste feedstock is presented. The interactions of the various types of waste feeds during co-pyrolysis were also reviewed. The applications of the products obtained as well as their further upgrading is also discussed. The presence of catalyst, reaction conditions, heating rate as well as the type of reactor, influence the yield as well as the composition of the products to a great extent. Pyrolysis of single feed as well as co-pyrolysis is also reviewed. Some co-pyrolysis studies reported better results than single feed pyrolysis owing to the synergistic interactions between waste feeds. This paper provides an overall outlook of the current scenario of the pyrolysis techniques for solid waste management.
\end{abstract}

\section{KEYWORDS}

Pyrolysis, Co-Pyrolysis, Solid Waste Management, Pyrolysis oil, Non-Volatile gases, Char.

\section{INTRODUCTION}

The challenges in ever-increasing amount of solid wastes has brought about noteworthy research in solid waste management.

Solid and Hazardous Waste Management Division, CSIR-National Environmental Engineering Research Institute, Nehru Marg, Nagpur 440020, Maharashtra, India.

*Corresponding author; email: gr_kale@neeri.res.in
Depending on nature and source of wastes, they can be classified as medical, industrial, agricultural, municipal, vehicular waste, etc. Currently, the major disposal techniques for waste management are: a) landfilling b) composting c) sewage treatment d) incineration and e) recycling (Rushton 2003). Out of these, recycling of wastes is restricted to only reusable wastes, while composting is restricted to biodegradable solid wastes and sewage treatment to sewage sludge. These methods require proper segregation of waste feedstock before disposal implementation. Majority of wastes are preferably landfilled due to its cheap and simple nature (Arsova et al. 2008). However, landfilling requires a huge land which leads to strain on land resources (Omar and Rohani 2015). The leaching out of heavily polluted leachates and emission of landfill gases from landfills has led to many harmful consequences on environment and people residing nearby (Bernard et al. 1996; Crowley et al. 2003; ElFadel et al. 1997; Vrijheid 2000). The leachates are a mixture of high concentration organic and inorganic contaminants including heavy metals and are highly toxic due to their synergistic or antagonistic effects and different physicalchemical properties of contaminants (Cameron and Koch 1980; Kjeldsen et al. 2002; Marttinen et al. 2002; Wiszniowski et al. 2006). Incineration allows better mass and volume reduction of wastes and good energy recovery and seems to be a better option than landfilling (Roy et al. 2011). However, the fly ash emissions released during incineration are hazardous due to high content of chlorides and fluorides, sulfur and nitrogen compounds, heavy metals like mercury and organic compounds. Some deadly sideeffects on human beings reported are congenital abnormalities, birth weight, twinning, still births, sex ratios, infant death, facial clefts, urinary tract defects, neral tube and heart defects (Ashworth et al. 2014; Margallo et al. 2015; van Velzen et al. 2002; Williams 1990). Sometimes greater amount of fuel is required to be supplied to ensure adequate combustion temperatures, 
making the incineration process less energy efficient (Ji et al. 2016; Yang et al. 2006).

Pyrolysis is a thermal degradation process of heating in absence of oxygen or air to produce gaseous components, tar and pyrolysis char residues (Ahmed and Gupta 2009). The pyrolysis process can be divided into three subclasses: conventional pyrolysis, fast pyrolysis, and flash pyrolysis (Demirbas and Arin 2002). Due to 'carbon negative' energy approach, pyrolysis deserves serious research and development worldwide for energy and controlling global warming (Lee et al. 2010). The liquid and gaseous fractions obtained are a valuable fuel source; while the solid fraction (char) has the potential of low grade carbon black or as carbon adsorbent (Lee et al. 2015; Martínez et al. 2013; Mohan et al. 2006b; Phan et al. 2008). Pyrolysis of waste also produces products that can be used as chemicals and high performance materials (carbon fibers and ceramics) other than fuels (Blazsó 1997). During recent years, pyrolysis has undergone an important evolution from a promising scientific idea to an alternative that is very close to reality with commercial opportunities (Aguado et al. 2008). Although the pyrolysis oils cannot be directly used as engine ready fuel but the fuel quality and contamination issues can be resolved by fuel additives and fuel finishing operations in terms of physical, catalytic and chemical upgrading (Butler et al. 2011a; Isahak et al. 2012).

Presently, fast pyrolysis of biomass is deemed as robust alternate technology for the paradigm shift from current crude oil fuel platform to a sustainable, more flexible fuel platform (Butler et al. 2011b). Based on ways of energy transfer, microwave assisted pyrolysis has an advantage of providing rapid and energy-efficient heating compared to conventional technologies, and thus facilitating increased production rates (Jones et al. 2002; Lam and Chase 2012). Hence pyrolysis can be a promising technique for waste management.

Literature has reported several significant reviews on the development of the pyrolysis process. Blazsó (1997) has reviewed the studies on the thermal decomposition mechanisms of polyolefines, polystyrenes, acrylic polymers, polyesters, polyethers, formaldehyde resins, polyamides, sulfur and silicon containing polymers. Aguado et al. (2008) have reviewed in detail the thermal and catalytic processes for recycling of plastics and several commercial processes for the preparation of diesel fuel. Butler et al. (2011a) has studied the state of art of commercial pyrolysis processes for the production of liquid transport fuels from waste polyolefins (polyethylenes and polypropylenes). Bulushev and Ross (2011) have reviewed chemistry of various catalytic processes for production and upgrading of the pyrolysis oils obtained from biomass pyrolysis. White et al. (2011) have reviewed the kinetic models and mathematical approximations currently employed in solid state thermal analysis and isoconversional model-fitting methods for estimating the related kinetic parameters. Isahak et al. (2012) have presented an updated review of biomass pyrolysis focusing on the characterization of feedstock, reactor design, product formation and physical, catalytic and chemical upgrading of the products. Jahirul et al. (2012) have discussed the status of biomass pyrolysis technology and its potential for commercial applications to produce bio-fuel in light of pyrolysis principles, biomass sources and characteristics, types of pyrolysis, reactor design, products and the economics of bio-fuel production. Mohan et al. (2006a) have reviewed in detail the pyrolysis of wood biomass and the characteristics of bio-oil produced. Butler et al. (2011b) have reviewed the laboratory work and developments on fast pyrolysis and upgrading techniques for its commercialization. Fonts et al. (2012) have reviewed the state of art of the sewage sludge pyrolysis for liquid production, focusing on the various factors influencing the process and chemical and physical properties of the pyrolysis oil obtained. Yang et al. (2013) have reviewed the pyrolysis of the waste electronic and electric plastic wastes and the dehalogenation of the pyrolysis oils.

A review based on the study of feedstock of pyrolysis and their interaction during copyrolysis has not been reported yet. The aim of this review is to study pyrolysis and co-pyrolysis focusing on the properties, composition and nature of waste feeds and their effect on the interactions during co-pyrolysis for solid waste 
management. The effect of the reaction conditions such as temperature, heating rate, presence of carrier gas, nature of catalyst on the yield and physicochemical properties of products are also discussed. The potential of pyrolysis products to serve as a source of high quality fuels and chemicals is also discussed. The review provides an outlook of waste pyrolysis from the aspect of feedstock, particularly required for an insight for waste-to-energy processes. The nature of interaction of the different feeds with each other and their effect on the yield and composition of the products during co-pyrolysis studied in this review provides a novel aspect in environmental engineering. Similar work has been reported previously by Sannita et al. (2012), but their study is restricted to triglyceride- based materials, wood and compounds derived from wood and few hydrocarbon and oxygenated polymers. This review includes pyrolysis of carbonaceous wastes including paper wastes.

\section{Single Feed Pyrolysis 1.1 Biomass}

Pyrolysis is a promising and environment friendly way of energy recovery from biomass as biomass is the only renewable source of fixed carbon (Bridgwater and Bridge 1991; SerranoRuiz and Dumesic 2011; Zhong et al. 2010). Considerable work has been reported to study the potential of agricultural wastes as a source of biofuels. Pyrolysis of rice husks (Meesuk et al. 2012; Williams and Nugranad 2000; Worasuwannarak et al. 2007), pine biomass (Aho et al. 2007), chlorella algae (Babich et al. 2011), wheat straw and husks (Krishna et al. 2015), beech wood (Stephanidis et al. 2011), combed cotton wastes (Barış̧̧ı and Öncel 2014), guayule (Boateng et al. 2016), douglas fir, para rubber seed (Chaiya and Reubroycharoen 2013), white ash, switchgrass, corn stover (Chen et al. 2016c), olive cake (Gercel and Gerçel 2007), miscanthus, douglas fir and oak (Le Brech et al. 2015), cassava plant residues (Pattiya 2011), mangaba seed (Santos et al. 2015), rapeseed cake (Smets et al. 2011), posidonia oceanica, lacustrine alga and white-pine (Chiodo et al. 2016), corn cob (Yu et al. 2010), tobacco wastes (Wu et al. 2015b) has been reported.

The yield and chemical composition of the products is influenced by a variety of factors such as temperature, presence of catalyst, size of the feed particles, etc. (Chaiya and Reubroycharoen 2013; Chen et al. 2016a; Demirbas 2010; Krishna et al. 2015). Various ways for upgrading the quality of the products, especially for use of pyrolysis oil as fuel have been reported.

One of the important products obtained during pyrolysis of the materials is bio-char. It possesses high calorific value and relatively low ash content making it suitable as a good solid fuel (Gil et al. 2012). Some other value-added products are also obtained. A high percentage of silica (88\%) was recovered from overall valorization of the bio-char of rice husk flash pyrolysis (Alvarez et al. 2014). Potassium silicate of electronic grade can be obtained from biochar more easily than from fusion of sand along with a good quality activated carbon as a byproduct (Jain et al. 1994). The char could be used as an additive material or good solid fuel with binders and additives due to its high energy content (Barışçı and Öncel 2014; Maiti et al. 2006). Due to good absorbing properties, biochar also finds its uses as adsorbent. The char obtained at high temperatures is highly porous with effective tar removal capacity (Paethanom and Yoshikawa 2012). Increase in the pyrolysis temperature increases the carbon content in biochar and gases (Chen et al. 2016c). The char is mainly aromatic polymer of carbon atoms ( $\mathrm{Hu}$ et al. 2008). Li et al. (2015a) have reported an increase in energy and char yield due to the effect of $\mathrm{NH}_{4} \mathrm{H}_{2} \mathrm{PO}_{4}$ on rice husk pyrolysis. Uzunov et al. (2012) have carried out fixed bed slow pyrolysis of rice husks for determining the effect of pyrolysis temperature on the properties of solid residues. Carbon black of high specific surface area and pore volume can be synthesized from rice husk by hydrolysis, carbonization and pyrolysis (Wang et al. 2011). Wu et al. (2015a) have suggested that the biochar from microwave pyrolysis is more uniform with less secondary bio-char which are produced from secondary reactions of volatiles.

Generally, the yield of non-condensable gases increases with increase in the temperature, lower heating rate and longer residence time (Khor et al. 2010). The yield also depends on the conditions, types of biomass and presence of 
catalyst (Buzetzki et al. 2012; Xie et al. 2015). Homma et al. (2013) have developed a new pyrolysis technology for wood pyrolysis that has a low manufacturing cost and less maintenance. It was quite feasible in rural areas and the gases obtained could be directly used in gas engine generator. The gases from rice husk pyrolysis can also be used in auto thermal pyrolysis process if the moisture content is controlled (Park et al. 2014). The gases obtained could be further reformed for the production of hydrogen gas (Uddin et al. 2014). Demirbaş (2005) has reported an increase in hydrogen production from agricultural residues via pyrolysis with an increase in temperature. The introduction of steam into the reactor system can drastically increase the hydrogen production (Adebanjo et al. 2007). The yeild of methane and hydrogen gases and heating value of the gases can be also increased by torrefaction pretreatment (Chen et al. 2015). The process of mild pyrolysis in the temperature range $200-350^{\circ} \mathrm{C}$ which leads to removal of water and volatiles through decomposition of hemicellulose in wood, is termed as torrefaction (Kolokolova et al. 2013). Zhang et al. (2015d) have reported the combined water washing-torrefaction pretreatment for effective removal of inorganics. The bio-char was obtained with huge surface area and had the potential to be used as soil ammendments.

The most important component obtained during pyrolysis is pyrolysis oil. Oil contains alkanes, alcohols, hydroxybenzenes, alkoxybenzenes, dioxolanes, aldehydes, ketones, carboxylic acids, esters, nitrogen-containing organic compounds (Lu et al. 2012). Due to its potential to be used as fuel, it can replace diesel and gas for on-site power generation and heating in furnaces, boilers, gas turbines etc.(Barth and Kleinert 2008; Zheng and Kong 2010) Literature has reported several methods to increase the quality and yield of pyrolysis oil. Bok et al. (2014) have designed a tilted-slide fast pyrolyzer with spray type condenser for the large-scale production of biocrude-oil from douglas fir in which the bio-oil from first and fourth condensers could be directly applied to conventional combustors. Kunkes et al. (2008) have reported the catalytic pyrolysis of biomass based on the integration of several flow reactors operated in cascade mode, where the effluent from the one reactor is fed to the next reactor and the first flow reactor contained monofunctional compounds, such as alcohols, ketones, carboxylic acids and heterocycles that could also be used to provide reactive intermediates for fine chemicals and polymers markets. Heo et al. (2010) have reported pyrolysis of rice husk in fluidized bed reactor in which the bio-oil production was most effective when the fluidizing medium was the product gas itself. Thangalazhy-Gopakumar et al. (2011) have reported large reduction in high molecular weight, oxygenated compounds in the pyrolysis oil when the carrier gas was changed from helium to hydrogen during pyrolysis. Williams and Besler (1993) have reported the pyrolysis study of rice husk in thermogravimetric analyzer and static batch reactor wherein water, $\mathrm{CO}$ and $\mathrm{CO}_{2}$ were evolved in lower temperature regime of decomposition and oil, water, hydrogen, hydrocarbon gases and lower concentrations of $\mathrm{CO}$ and $\mathrm{CO}$ were evolved in higher temperature regime. Le Brech et al. (2015) have reported the pyrolysis in U-shaped fixed bed reactor which allowed external mass transfer control, bed temperature control and char quenching at targeted temperatures. Undri et al. (2014b) have reported microwave assisted pyrolysis of corn derived plastic bags which can avoid the anaerobic digestion of these bags without any energy recovery. Gercel and Gerçel (2007) have pyrolysed olive cake and found that at optimum conditions, the calorific value of pyrolysis oil is very close to those of petroleum fractions. Santos et al. (2015) have reported that the biooil from pyrolysis of mangaba seed was promising as fuel after upgradation due to the presence of long chain acids. Demirbas (2009) have pyrolysed olive husk, hazelnut shell, spruce wood, and beech wood samples and reported that the density of bio-oil was 1,170-1,230 $\mathrm{kg} / \mathrm{m}^{3}$, compared to $800-100 \mathrm{~kg} / \mathrm{m}^{3}$ of heavy petroleum oil.

Guha et al. (1987) have studied the potential use of pyrolysis oil in germicide manufacture due to the presence of toxic phenolic compounds. Ji-Lu (2007) has conducted pyrolysis of rice husk and reported that the bio-oil can be directly used in boiler or furnace without further upgrading and the cost of pyrolysis can be greatly reduced by 
using charcoal combustion for heating and hot flue gas as carrier gas. Torri et al. (2016) have reported an increase in the percentage of aromatic hydrocarbons in bio-oil during catalytic fast pyrolysis of softwood, thus indicating its potential as liquid fuel. Lu et al. (2011) have proposed low temperature fast pyrolysis of biomass impregnated with zinc chloride to obtain furfural from bio-oil while acetic acid was obtained as by-product. The addition of methanol stabilized the bio-oil and enhanced the quality by decreasing viscosity and ageing rates of bio-oil (Lu et al. 2008). Li et al. (2012) have seen an increase in the yield of water soluble organics and heating value with decrease in acetic acid content and ring opening reactions of cellulose during fast pyrolysis of rice husk with mineral bed materials. Qian et al. (2014) have reported the facilitation of dehydration and decarboxylation of higher calorific value bio-oil under elevated pressure in the pyrolysis of rice husk. Banks et al. (2014) have reported that during pyrolysis of Miscanthus pretreated with Triton X-100 surfactant, the best quality organic oil was produced with highest concentration of Triton $X$ 100 surfactant. Shen et al. (2015) have reviewed the opportunities of the fast pyrolysis products as value added chemicals and fuels. Damartzis and Zabaniotou (2011) have discussed the emerging challenges and opportunities of the applications of process integration on chemical conversion of biomass to second generation liquid biofuels.

Chen et al. (2011) have reported a decrease in the total bio-oil content, higher water content, higher $\mathrm{pH}$, and lower alkali metal content in the bio-oil when the hot vapor filtration of bio-oil was conducted. It was also reported that the PAH content increased when the temperature increased and around $800^{\circ} \mathrm{C}$ charcoal liquid was produced (Zhai et al. 2015). Catalysis is one of the assuring approaches for upgrading the biooil. The use of catalyst decreased the bio-oil yield, but enhanced the small molecular compound yield and decreased the amount of oxygenated groups in bio-oils (Bridgwater 1996; Zhou et al. 2013). The pyrolysis oil before catalysis was homogeneous, of low viscosity and highly oxygenated with presence of polycyclic aromatic hydrocarbon (PAH) in low concentration (Williams and Nugranad 2000). Aho et al. (2007) have reported the formation of less organic oil and more water and PAH on the catalytic pyrolysis of pine biomass with zeolites of stronger acidity. Antonakou et al. (2006) have proposed the use of mesoporous catalysts $\mathrm{Fe}-$ Al-MCM-41 and Cu-Al-MCM-41 as best metal containing catalyst for phenol production from bio-oil. The phenol concentration can be further increased by upgrading of the bio-oil obtained from hydrothermally pretreated biomass (Stephanidis et al. 2011). Phenol could be further used in adhesive industry (Effendi et al. 2008). Wang et al. (2010) have reported an increased yield of gaseous and char products with use of $\mathrm{K}_{2} \mathrm{CO}_{3}$ as a stronger catalyst for decomposition of hemicellulose, cellulose and lignin constituents. Various pretreatment techniques and product upgrading via catalysis also facilitate increase in the quality of the biooil. Bridgwater and Bridge (1991); French and Czernik (2010), Galadima and Muraza (2015) have studied the catalytic upgrading of the primary fast pyrolysis products for removing oxygen from organic compounds to give aromatics and other hydrocarbon products. The products can be further converted into gasoline and diesel and the condensed liquid can be hydrotreated to a naphtha like product also for up gradation into transport fuels (Kim et al. 2013).

The hydroprocessing increases the intrinsic hydrogen content of the pyrolysis oil, producing polyols and alcohols. The zeolite catalyst then converts these hydrogenated products into light olefins and aromatic hydrocarbons as much as three times higher than that produced with the pure pyrolysis oil (Vispute et al. 2010). Babich et al. (2011) had pretreated chlorella algae with $\mathrm{Na}_{2} \mathrm{CO}_{3}$ and the decomposition temperature shifted to lower value, yield of gas increased and yield of liquid decreased. Barış̧̧ı and Öncel (2014) have reported that bio-char from pyrolysis of combed cotton wastes in a fixed bed reactor with $\mathrm{Na}_{2} \mathrm{CO}_{3}$ and $\mathrm{CaCO}_{3}$ as catalyst can be used as additive material or fuel due to its high energy potential. Meesuk et al. (2012) have further reported that the quality of the bio-oil can be further improved to a level suitable for a potential liquid fuel and chemical feedstock by hydropyrolysis of rice husk using $\mathrm{Ni} / \mathrm{LY}$ char at 
high temperature and the pyrolysis oil contained less acids, higher aromatics and showed higher heating value leading to $40 \%$ energy recovery in bio-oil. Zhang et al. (2015a) have studied the microwave assisted catalytic fast pyrolysis of biomass using HZSM-5 catalyst and reported that the relative contents of the aliphatic hydrocarbons, aromatic hydrocarbons and oxygen-containing aromatic compounds first increased and then decreased, whereas the relative content of oxygen-containing aliphatic compounds first decreased and then increased.

\subsection{Paper wastes}

Paper industry generates a significant amount of wastes and the waste composition depends on the type of paper produced and the origin of cellulose fibres. (Méndez et al. 2009). Nearly 11 million tons of paper wastes are generated per year by European pulp and paper industry, of which $70 \%$ originated from the production of deinked recycled paper. The paper and pulp production from virgin pulp generates less wastes with less organics than deinked pulp (Monte et al. 2009). Paper mill sludge contain massive heavy metal, pathogen and parasites making it very easy to corrupt and produce odor causing secondary pollution to the environment and threat to human beings and animals (Liu et al. 2010). Therefore one of the most important tasks for environmental protection is the safe disposal of sludge from paper and pulp industry (Yu et al. 2002).

The four main compounds in bio-oil obtained from waste paper pyrolysis are anhydrosugar, carboxyl compounds, carbonyl compounds and aromatic compounds (Li et al. 2005). The gases generated during pyrolysis of newspaper wastes are composed of $\mathrm{H}_{2}, \mathrm{CO}, \mathrm{CO}_{2}$, and $\mathrm{CH}_{4}$ with a trace amount of $\mathrm{C}_{2} \mathrm{H}_{4}$ and $\mathrm{C}_{2} \mathrm{H}_{6}$ and the production of hydrogen rich gaseous fuel is favored at higher temperature and higher retention time (Bhuiyan et al. 2009). It was also reported that there is an increase in the yield of liquid and gaseous products with an increase in the solid waste pyrolysis temperature (Demirbaş 2002), and char yield increases with an increase in the heating rate (Gupta et al. 1999). The performance of fast pyrolysis for energy transfer from paper waste sludge to liquid and solid products is considerable higher than vacuum and slow pyrolysis due to higher yield of condensable organic compounds and less water content (Ridout et al. 2016). Fast pyrolysis is quite promising due to low optimal reactor temperatures and high bio-oil yield. The noncondensable gas yield increases due to promotion of exothermic reaction for high heating rates (Ridout et al. 2015). Biswal et al. (2013) have pyrolysed paper cup waste in a stainless steel semibatch reactor and found that the pyrolytic liquid contains around 18 types of compounds having carbon chain length in the range of $C_{6}-C_{20}$, and can be used as valuable chemical feedstock. Jiang and Ma (2011) have reported that microwave pyrolysis of paper mill sludge was best performed when $5 \% \mathrm{NaOH}$ was added as microwave absorber in $\mathrm{CO}_{2}$ atmosphere. Reckamp et al. (2014) have subjected paper mill sludge to a combination of acid hydrolysis and torrefaction pretreatment and found that the bio-char yield was higher and ideal to be used as soil amendment agent or sorbent material. Mendez et al. (2014) have reported the use of bio-char from deinking paper sludge pyrolysis to treat nickel polluted soil.

Calisto et al. (2014) have reported production of adsorbents obtained in the pyrolysis of paper mill sludge for the removal of highly consumed antidepressant (citalopram) from water. Devi and Saroha (2015) have studied the PAH toxicity and sorption behavior of bio-char obtained in the pyrolysis of paper mill effluent treatment plant and reported that the concentration of PAHs in bio-char were within the permissible limits prescribed by US EPA. Strezov and Evans (2009) have reported that a large fraction of mineral matter (56\%) in the charcoal produced by pyrolysis of dry paper sludge and also found that the energy from bio-gas can utilized to recover the heat required for pyrolysis thus reducing the external heat supply requirement. Zhang et al. (2015g) have reported low temperature microwave assisted pyrolysis of paper deinking residue for simultaneously efficient fast recovery and separation of organic and inorganic content in which the organic fraction of bio-oil generated was a potential source of valuable aromatic compounds. Zhang et al. (2015f) have further reported the low temperature microwave assisted fast pyrolysis 
of waste office papers (printed or photocopied) and the application of bio-oil as adhesive for aluminum-aluminum bonding.

\section{Co-pyrolysis of carbonaceous mixed feeds 2.1 Biomass with other feeds}

The oil obtained from pyrolysis needs upgrading due to considerable amounts of oxygen in them making them unsuitable as a fuel due to low caloric value, corrosion problems, and instability. Generally upgrading is done by addition of a catalyst, solvent and large amount hydrogen, which make the process less cost efficient due to high costs of the additions (Abnisa and Daud 2014; Lee and Kim 2015). Therefore co-pyrolysis of wastes has gained importance due to the certain synergistic effects such as higher quantity and better quality of oil or limited supply of certain feedstock which thus improves the overall pyrolysis process (Oyedun et al. 2014; Sarkar and Chowdhury 2014). Liu et al. (2013) have reported the synergistic effects of the WEEEs and biomass occurring during the co-pyrolysis due to significantly higher yield of bio-oil than individual pyrolysis of components with no formation of polybrominated dibenzo-pdioxins. Sajdak and Muzyka (2014) have reported a reduction in heat energy requirement during co-pyrolysis of plastics with biomass thus showing synergistic effects. Xue et al. (2015) have observed an increase in the production of furan, acids and water with improved higher heating value of the resulting char due to significant synergetic effects during co-pyrolysis of red oak and high-density polyethylene (HDPE). Wang et al. (2016c) have reported an increase in gas and liquid yields but a decrease in char yield due to the synergetic effect during the co-pyrolysis of sewage sludge and wheat straw which also accelerated the pyrolysis reactions. Zhang et al. (2015c) have reported significant promotion of aromatics due to synergistic effect between corn stalk and food waste thus making catalytic co-pyrolysis an efficient method for production of aromatics and other petrochemicals.

Several studies on the products of biomass copyrolysis have been done. Goldfarb and Ceylan (2015) have studied the sustainability of second generation fuels by pyrolysis of highly volatile bituminous Pennsylvanian coal blended at 90,
80 , and $50 \mathrm{wt} \%$ with one of three biomasses: feed corn stover, brewer's spent grains or cocoa shells. Paradela et al. (2009) have performed slow batch co-pyrolysis using mixtures of plastics, tires and forestry biomass wastes and found that the plastic content in the mixture affects the product yield and composition greatly. Ro et al. (2014) have performed copyrolysis of swine manure with agricultural plastic waste and reported the potential of using pyrolysis technology to manage two prominent agricultural waste streams (spent plastic mulch films and swine solids) along with production of value-added biochar that could be used as a power source for local farm operations. Uzun and Yaman (2014) have reported the copyrolysis of scrap tire and Juglans regia shell as environmental friendly process for production of valuable chemicals and fuels from the wastes.

Alvarez et al. (2015) have studied the copyrolysis of the sewage sludge and lignocellulosic biomass in a conical spouted bed reactor and reported minimization of the gas production reactions from bio-oil (mainly promoted by the catalytic activity of the ash in the sludge). Zhang et al. (2014) have carried out co-pyrolysis of pine sawdust and plastics (polyethylene, polypropylene, and polystyrene) in a catalytic fluidized bed reactor in order to improve the yield of hydrocarbons (aromatics and olefins). Zhou et al. (2015a) have conducted co-pyrolysis of three municipal solid waste (MSW) components (rice, poplar wood and PVC) and reported an increase in the generation of $\mathrm{CO}_{2}$ and $\mathrm{CO}$ at slower rate. Zhou et al. (2015c) have co-pyrolysed polyvinyl chloride (PVC) and biomass components (hemi-cellulose, cellulose and lignin) and have reported decrease in $\mathrm{HCl}$ and PAH yields and significant increase in tar yield. Onal et al. (2014) have carried out copyrolysis of almond shell as biomass and highdensity polyethylene and found that the oils produced were having higher carbon (26\% higher) and hydrogen content (78\% higher), lower oxygen content (\%86 less) with a higher heating value (38\% higher) than those of biomass oil.

Further upgrading of the product can be done by catalytic co-pyrolysis. Jin and Wang (2015) have reported equal mean temperature of mass loss 
of the pyrolysis oil of rice husk and waste tires in 1:1 ratio with SBA-15 catalyst and diesel, thus showing similar evaporation properties of pyrolysis oil and diesel. Pinto et al. (2013) have reported response surface methodology as a method for prediction of liquid yields from the pyrolysis of waste mixtures consisting of $10 \%$ of pine, $10 \%$ of scrap tyres and $80 \%$ recycled plastic as a suitable method for optimizing the experimental conditions that favor the formation of desired gaseous and liquid compounds. Yao et al. (2015) have reported ZSM-5 modification with $\mathrm{P}$ and $\mathrm{P} / \mathrm{Ni}$ for improvement of catalyst's activity and life time for co-pyrolysis of biomass and plastics. Zhang et al. (2015b) have reported catalytic co-pyrolysis of corn stalk and high density polyethylene (HDPE) over HZSM-5 zeolite catalyst for promoting efficient production of aromatic hydrocarbons. Luo and Fu (2015) have reported the use of biomass tar for the production of directly reduced iron by co-pyrolysis of biomass tar and iron ore fines. Zhang et al. (2015e) have carried out co-pyrolysis of sewage sludge and biomass in a vacuum reactor and reported higher gas yield of the blend fuel than both the individual parent fuels thus approving the method feasible for fuel production. Zhang et al. (2011) have studied fraction distribution of heavy metals in co-pyrolysis of sewage sludge and corn straw and reported that the carbon residues obtained were nonhazardous and safe.

\subsection{Coal and RDF with other feeds}

Co-pyrolysis with coal is a good waste management option due to high energy obtained during pyrolysis as well as co-pyrolysis of the coal (Coimbra et al. 2015). The composition and quantity of products during these processes depend greatly on the coal type, pyrolysis temperature and heating method (Ding et al. 2015). The evolution of gases is increased by rising the temperature and longer residence time resulting into secondary cracking of tar and gaseous hydrocarbons (Reichel et al. 2015). During coal pyrolysis, there is a decrease in the differences in the nitrogen distribution in the char precursors to the extent that it cannot influence the formation of nitrogen oxides during combustion of chars significantly (Pels et al. 1995). The formation of $\mathrm{NH}_{3}$ can be promoted by the presence of $\mathrm{NaOH}, \mathrm{KOH}$ and $\mathrm{Ca}(\mathrm{OH})_{2}$ which however suppresses HCN formation (Ohtsuka et al. 1997). Similarly, sulfur containing gases are evolved during coal pyrolysis and copyrolysis (Calkins 1987; Cleyle et al. 1984). Wang et al. (2016a) have reported $\mathrm{CO}_{2}$ atmosphere to be very beneficial for release of $\mathrm{H}_{2} \mathrm{~S}, \mathrm{COS}$ and $\mathrm{SO}_{2}$ into gas phase during pyrolysis, thus removing the sulfur from coals. Pyrolysis of refuse derived fuel (RDF) which is generated from municipal solid waste treatment plants is a temperature dependent energy recovery process (Manyà et al. 2015; Tippayawong et al. 2008).

Bicakova and Straka (2016) have co-pyrolysed waste tire/coal mixtures and reported the production of smokeless fuel/carbonaceous sorbent along with a high yield of tar and gases with high amount of hydrogen and methane. Melendi-Espina et al. (2015) have reported synergistic effect between coal and plastic wastes which changed the composition of the volatiles evolved, promoted interactions between the components and had negative effects on coal fluidity. Montiano et al. (2016) have carried out pyrolysis of two types of coals, sawdust and coal tar and reported independent thermal decomposition of the components without any apparent synergism and Alias et al. (2012) also found similar results during copyrolysis of the coal and Refuse Derive Fuel (RDF). Lei et al. (2016) have reported pretreatment of lignite coal with ionic liquids at low temperature leading to the increase in yield of oil fractions in the products. Tyler (1980) have reported flash pyrolysis of bituminous coal in a small scale fluidized bed reactor with an increase in the yield of $\mathrm{CH} 4$ in $\mathrm{H} 2$ atmosphere. Rizkiana et al. (2016) have reported an improvement in the quality of co-pyrolysis oil of low-rank coal and biomass in presence of $\mathrm{Mg}$-modified ultra-stable Y type zeolite. Whyte et al. (2015) have reported the formation of catalytic bio-oil from pyrolysis of RDF char and oyster shell with similar density, heating value and viscosity as conventional diesel fuel. Tang et al. (2015) have reported an interactive effect during co-pyrolysis of Shenmu coal and cotton stalk leading to an increased tar yield. Vamvuka et al. (2003) pyrolysed olive kernel, forest and cotton residues mixed with lignite coal and reported higher thermochemical reactivity which make them 'solid biofuels' 
which can produce faster and higher quantity of volatile compounds in fast kinetics.

\subsection{Municipal solid wastes}

Pyrolysis of municipal solid wastes is an attractive alternative to incineration for energy and resource recovery (Chen et al. 2014). The product yield and composition is affected largely by the feedstock, the pyrolysis temperature, the heating rate and the type of reactor adopted (Han et al. 2015; Nurul Islam et al. 2005). Several studies have been reported for the influence of synergetic interactions during co-pyrolysis of various feeds. Zuo et al. (2014) have conducted co-pyrolysis of sewage sludge and popular sawdust and reported characteristic change in the top phase oil due to the synergetic reactions that took place during co-pyrolysis. Zhou et al. (2014) have co-pyrolysed orange peel, tissue paper and PVC from MSW and reported that the production of alkyls and alkenes was inhibited during pyrolysis at low temperature and residue increased. Zhou et al. (2015b) have reported intense interactions between PVC and rice, poplar wood, tissue paper, wool, terylene, and rubber powder during their co-pyrolysis leading to promotion of low temperature pyrolysis. Fang et al. (2015) have co-pyrolysed paper sludge and municipal solid wastes in different proportions and different heating rates and reported an increase in the initial temperature with increase in paper sludge proportion. Ren et al. (2009) have conducted co-pyrolysis of cotton stalk and municipal solid wastes with high ash content and low calorific value and reported an increase in weight loss as well as $\mathrm{NH}_{3}$ emissions with an increase in mass proportion of stalk. Wang et al. (2016b) have reported co-pyrolysis of microalgae and sewage sludge as a promising way to decrease feedstock cost and realize alternative fuel production and to avoid the high ash content and low heat value.

A few negative synergistic effects have also been reported in literature. Kim et al. (2010) have reported negligible interactions between the components of the feed during the co-pyrolysis of different components of municipal solid wastes (polyethylene, cellulose, lignin and sawdust from vinal wood). Wu et al. (1997) have reported insignificant effect of interactions on the rate of pyrolysis of paper mixture from municipal solid wastes. Chen et al. (2016b) have reported negative synergistic effects during the co-pyrolysis of pork and polypropylene leading to hindered rate of pork pyrolysis and lower weight loss of the blends than the individual feeds. Fang et al. (2016) have studied the effect of $\mathrm{MgO}$ (magnesium oxide), $\mathrm{Al}_{2} \mathrm{O}_{3}$ (alumina) and $\mathrm{ZnO}$ (zinc oxide) additives and reported reduction of initial temperatures and activation energies. AlOthman et al. (2011) have reported the formation of activated carbon with high adsorption efficiency during co-pyrolysis of mixed solid wastes (biomass, cartons and polystyrene) at low carbonization temperatures. Cao et al. (2014) have developed a novel and improved waste pyrolysis test system with efficient rotary pyrolysis kiln working and high calorific power composite gas generation efficiency.

\section{CONCLUSION}

Pyrolysis can be universally applied to all sorts of carbonaceous wastes with excellent energy and material recovery. The products obtained can not only be used as fuels due to their high calorific value, but also can be a source of many valuable chemicals required in industry. Due to mass and volume reduction to great extent, it can lessen the pressure on land resources caused due to landfilling while the reaction time is very short and hence can be used in small systems with high throughput. Further research is required product upgrading and commercialization of the process. Co-pyrolysis can provide cheap and assuring approach for this purpose. More studies on the interactions of feeds during co-pyrolysis are required. The presence of halides, sulfides and heavy metals in the products can pose a severe challenge to the use of these products. Use of catalyst, microwave assisted heating, various pretreatment processes, efficient reactor design and optimum reaction conditions can improve the quality as well quantity of the desired products. 


\section{REFERENCES}

Abnisa, F. Daud, WMAW. 2014, 'A review on copyrolysis of biomass: An optional technique to obtain a high-grade pyrolysis oil', Energy Convers Manage, vol.87, pp.71-85.

Adebanjo, A., Kulkarni, MG., Dalai, AK., Bakhshi, NN., 2007, 'Pyrolysis of waste fryer grease in a fixed-bed reactor', Energ Fuel, vol.21, pp.828-835.

Aguado, J., Serrano, DP., Escola, JM., 2008, 'Fuels from Waste Plastics by Thermal and Catalytic Processes', A Review Industrial \& Engineering Chemistry Research, vol.47, pp.7982-7992

Ahmed, I. Gupta, AK. 2009, 'Syngas yield during pyrolysis and steam gasification of paper', Applied Energy, vol.86, pp.1813-1821.

Aho, A., Kumar, N., Eränen, K., Salmi, T., Hupa, M., Murzin, DY., 2007, 'Catalytic pyrolysis of biomass in a fluidized bed reactor: influence of the acidity of $\mathrm{H}$ beta', zeolite Process Safety and Environmental Protection, vol. 85, pp.473-480.

Alias, AB., Rashid, ZA., Abdul Rahman, N., Wan, Ab., Karim Ghani, WA., 2012, 'Thermal behaviour study of senakin coal and Refuse Derived Fuel (RDF) blends during pyrolysis using thermogravimetric analysis', International Journal of Environment and Waste Management, vol.10, pp.354-364.

AlOthman, Z., Habila, M., Ali, R., 2011, 'Preparation of activated carbon using the copyrolysis of agricultural and municipal solid wastes at a low carbonization temperature carbon', International Conference on Biology, Environment and Chemistry (IPCBEE), vol.24, Alvarez, J., Amutio, M., Lopez, G., Bilbao, J., Olazar, M., 2015, 'Fast co-pyrolysis of sewage sludge and lignocellulosic biomass in a conical spouted bed reactor', Fuel, vol.159, pp.810-818.

Alvarez, J., Lopez, G., Amutio, M., Bilbao, J., Olazar, M., 2014, 'Upgrading the rice husk char obtained by flash pyrolysis for the production of amorphous silica and high quality activated carbon', Bioresour Technol, vol.170 pp.132-137.

Antonakou, E., Lappas, A., Nilsen, MH., Bouzga, A., Stöcker, M., 2006, 'Evaluation of various types of AlMCM-41 materials as catalysts in biomass pyrolysis for the production of bio-fuels and chemicals', Fuel, vol.85, pp.2202-2212.

Arsova, L., Van Haaren, R., Goldstein, N., Kaufman, SM., Themelis, NJ. 2008, '16th NATIONWIDE SURVEYTHE STATE OF GARBAGE IN AMERICA- Latest national data on municipal solid management--29 percent recycled and composted, 7 percent combusted in waste-to-energy plants and 64 percent landfilled', BioCycle. vol.49, no.12. pp.22.

Ashworth, DC., Elliott, P., Toledano, MB., 2014, 'Waste incineration and adverse birth and neonatal outcomes: a systematic review', Environ Int, vol.69, pp.120-132.
Babich, I., Van der Hulst, M., Lefferts, L., Moulijn, J., O'Connor, P., Seshan, K., 2011, 'Catalytic pyrolysis of microalgae to high-quality liquid bio-fuels', Biomass Bioenergy, vol.35, pp.3199-3207.

Banks, SW., Nowakowski, DJ., Bridgwater, AV., 2014, 'Fast pyrolysis processing of surfactant washed Miscanthus', Fuel Process Technol, vol.128, pp.94103.

Barışçı, S. Öncel, MS. 2014, 'The Disposal of combed cotton wastes by pyrolysis', International Journal of Green Energy, vol.11, pp.255-266.

Barth, T., Kleinert, M. 2008, 'Motor fuels from biomass pyrolysis', Chemical engineering \& technology'. vol.31, pp.773-781.

Bernard, C., Guido, P., Colin, J., Le Dû-Delepierre, A. 1996, 'Estimation of the hazard of landfills through toxicity testing of leachates-I. Determination of leachate toxicity with a battery of acute tests', Chemosphere vol. 33, no. 11, pp.2303-2320.

Bhuiyan, M., Ota, M., Murakami, K., Yoshida, H., 2009, 'Pyrolysis kinetics of newspaper and its gasification', Energy Sources Part A: Recovery, Utilization, and Environmental Effects, vol.32, pp.108-118.

Bicakova, O., Straka, P. 2016, 'Co-pyrolysis of waste tire/coal mixtures for smokeless fuel, maltenes and hydrogen-rich gas production', Energy Convers Manage. vol.116, pp.203-213.

Biswal, B., Kumar, S., Singh, R. 2013, 'Production of hydrocarbon liquid by thermal pyrolysis of paper cup waste', Journal of Waste Management, 731858.

Blazsó, M. 1997, 'Recent trends in analytical and applied pyrolysis of polymers', J Anal Appl Pyrolysis, vol.39, pp.1-25.

Boateng, AA., Elkasabi, Y., Mullen, CA., 2016, 'Guayule (parthenium argentatum) pyrolysis biorefining: fuels and chemicals contributed from guayule leaves via tail gas reactive pyrolysis', Fuel, vol. 163, pp.240-247.

Bok, JP., Choi, YS., Choi, SK., Jeong, YW., 2014, 'Fast pyrolysis of Douglas fir by using tilted-slide reactor and characteristics of biocrude-oil fractions', Renewable Energy, vol. 65, pp.7-13.

Bridgwater, A. 1996, 'Production of high grade fuels and chemicals from catalytic pyrolysis of biomass', Catal Today. vol. 29, pp.285-295.

Bridgwater, AV. Bridge, SA. 1991, 'A Review of Biomass Pyrolysis and Pyrolysis Technologies. In: Bridgwater AV, Grassi G (eds) Biomass Pyrolysis Liquids Upgrading and Utilization', Springer Netherlands, Dordrecht. pp.11-92.

Bulushev, DA. Ross, JRH. 2011, 'Catalysis for conversion of biomass to fuels via pyrolysis and gasification', A review Catal Today, vol. 171, pp.1-13. Butler, E., Devlin, G., McDonnell, K., 2011a, 'Waste Polyolefins to Liquid Fuels via Pyrolysis: Review of Commercial State-of-the-Art and Recent Laboratory 
Research', Waste and Biomass Valorization, vol. 2, pp.227-255.

Butler, E., Devlin, G., Meier, D., McDonnell, K., 2011b, 'A review of recent laboratory research and commercial developments in fast pyrolysis and upgrading', Renewable and Sustainable Energy Reviews, vol. 15, pp.4171-4186.

Buzetzki, E., Rimarčík, J., Cvengrošová, Z., Kleinová, A., Sarközy, I., Cvengroš, J., 2012, 'Liquid Fuels from Biomass Cracking', Procedia Engineering. vol.42, pp.1133-1136.

Calisto, V., Ferreira, CIA., Santos, SM., Gil, MV., Otero, M., Esteves, VI., 2014, 'Production of adsorbents by pyrolysis of paper mill sludge and application on the removal of citalopram from water', Bioresour Technol. vol. 166, pp.335-344.

Calkins, WH. 1987, 'Investigation of organic sulfurcontaining structures in coal by flash pyrolysis experiments', Energ Fuel, vol. 1, pp.59-64.

Cameron, RD. Koch, FA. 1980, 'Trace Metals and Anaerobic Digestion of', Leachate Journal (Water Pollution Control Federation). vol. 52, pp.282-292.

Cao, W., Zha, WW., Ni, WL. 2014, 'A design of pyrolysis test system based on the co-processing of municipal waste with rotary klin', Appl Mech Mater. vol. 675-677, pp.693-697.

Chaiya, C. Reubroycharoen, P. 2013, 'Production of Bio Oil from Para Rubber Seed', Using Pyrolysis Process Energy Procedia, vol.34, pp.905-911.

Chen, D., Yin, L., Wang, H., He, P., 2014, 'Pyrolysis technologies for municipal solid waste $A$ review', Waste Manage (Oxford). vol.34, pp.2466-2486.

Chen, D., Zheng, Z., Fu, K., Zeng, Z., Wang, J., Lu, M., 2015, 'Torrefaction of biomass stalk and its effect on the yield and quality of pyrolysis products', Fuel, vol. 159, pp.27-32.

Chen, F., Wu, C., Dong, L., Vassallo, A., Williams, PT., Huang, J., 2016a, 'Characteristics and catalytic properties of $\mathrm{Ni} / \mathrm{CaAlOx}$ catalyst for hydrogenenriched syngas production from pyrolysis-steam reforming of biomass sawdust', Applied Catalysis B: Environmental. vol. 183, pp.168-175.

Chen, L., Wang, SZ., Wu, ZQ., Meng, HY., Zhao, J., Lin, ZH. 2016b, 'Investigation on Thermal and Kinetic Characteristics during Pyrolysis and Co-Pyrolysis of Recovered Fuels Obtained from Municipal Solid Waste in China', Proceedings of the Asme Power Conference.

Chen, T., Liu, R., Scott, NR., 2016c, 'Characterization of energy carriers obtained from the pyrolysis of white ash, switchgrass and corn stover-Biochar, syngas and bio-oil', Fuel Process Technol, vol. 142, pp.124-134.

Chen, T., Wu, C., Liu, R., Fei, W., Liu, S., 2011, 'Effect of hot vapor filtration on the characterization of biooil from rice husks with fast pyrolysis in a fluidized- bed reactor', Bioresour Technol, vol. 102, pp.61786185.

Chiodo, V., Zafarana, G., Maisano, S., Freni, S., Urbani, F., 2016, 'Pyrolysis of different biomass: Direct comparison among Posidonia Oceanica', Lacustrine Alga and White-Pine Fuel, vol. 164, pp.220-227.

Cleyle, PJ., Caley, WF., Stewart, L., whiteway, SG. 1984, 'Decomposition of pyrite and trapping of sulphur in a coal matrix during pyrolysis of coal', Fuel, vol. 63, pp.1579-1582.

Coimbra, RN., Paniagua, S., Escapa, C., Calvo, LF., Otero, M., 2015, 'Thermogravimetric analysis of the co-pyrolysis of a bituminous coal and pulp mill sludge', J Therm Anal Calorim. vol. 122, pp.13851394.

Crowley, D., et al. 2003, 'Health and environmental effects of landfilling and incineration of waste-A literature review, Dublin Institute of Technology.

Damartzis, T. Zabaniotou, A. 2011, 'Thermochemical conversion of biomass to second generation biofuels through integrated process design', $A$ review Renewable and Sustainable Energy Reviews, vol. 15, pp.366-378.

Demirbas, A. 2009, 'Fuel properties of pyrolysis oils from biomass', Energy Sources Part A, vol. 31, pp.412-419.

Demirbaş, A. 2002, 'Utilization of urban and pulping wastes to produce synthetic fuel via pyrolysis', Energy sources, vol. 24, pp.205-213.

DemirbaŞ, A. 2005, 'Hydrogen Production via Pyrolytic Degradation of Agricultural Residues', Energy Sources, vol. 27, pp.769-775.

Demirbas, A. Arin, G. 2002, 'An overview of biomass pyrolysis', Energy sources, vol. 24, pp.471-482.

Demirbas, M. 2010, 'Characterization of bio-oils from spruce wood (Picea orientalis L.) via pyrolysis', Energy Sources, Part A: Recovery, Utilization, and Environmental Effects. vol. 32, pp.909-916.

Devi, P., Saroha, AK. 2015, 'Effect of pyrolysis temperature on polycyclic aromatic hydrocarbons toxicity and sorption behaviour of biochars prepared by pyrolysis of paper mill effluent treatment plant sludge', Bioresour Technol, vol. 192, pp.312-320.

Ding, L., Zhou, Z., Dai, Z., Yu, G. 2015, 'Effects of coal drying on the pyrolysis and in-situ gasification characteristics of lignite coals', Applied Energy. vol. 155, pp.660-670.

Effendi, A., Gerhauser, H., Bridgwater, AV. 2008, 'Production of renewable phenolic resins by thermochemical conversion of biomass a review', Renewable and Sustainable Energy Reviews, vol. 12, pp.2092-2116.

El-Fadel, M.,Findikakis, AN.,Leckie, JO. 1997,'Environmental Impacts of Solid Waste Landfilling', Journal of Environmental Management, vol. 50 ,pp.1-25. 
Fang, SW., Yu, ZS., Lin, Y., Lin, YS., Fan, YL., Liao, YF., $\mathrm{Ma}, \mathrm{XQ}$. 2016, 'Effects of additives on the co-pyrolysis of municipal solid waste and paper sludge by using thermogravimetric analysis', Bioresour Technol, vol. 209, pp.265-272.

Fang, SW., Yu, ZS., Lin, YS., Hu, SC., Liao, YF., Ma, XQ., 2015, 'Thermogravimetric analysis of the co-pyrolysis of paper sludge and municipal solid waste', Energy Convers Manage, vol. 101, pp.626-631.

Fonts, I., Gea, G., Azuara, M., Ábrego, J., Arauzo, J., 2012, 'Sewage sludge pyrolysis for liquid production a review', Renewable and Sustainable Energy Reviews, vol. 16, pp.2781-2805.

French, R., Czernik, S., 2010, 'Catalytic pyrolysis of biomass for biofuels production', Fuel Process Technol, vol. 91, pp.25-32.

Galadima, A., Muraza, O. 2015, 'In situ fast pyrolysis of biomass with zeolite catalysts for bioaromatics/gasoline production a review', Energy Convers Manage, vol.105, pp.338-354.

Gercel, H. Gerçel, Ö. 2007, 'Bio-oil production from an oilseed by-product: fixed-bed pyrolysis of olive cake', Energy Sources Part A, vol. 29, pp.695-704.

Gil, R., Girón, R., Lozano, M., Ruiz, B., Fuente, E. 2012, 'Pyrolysis of biocollagenic wastes of vegetable tanning. Optimization and kinetic study', J Anal Appl Pyrolysis, vol. 98, pp.129-136.

Goldfarb, JL. Ceylan, S. 2015, 'Second-generation sustainability: Application of the distributed activation energy model to the pyrolysis of locally sourced biomass-coal blends for use in co-firing scenarios', Fuel, vol. 160, pp.297-308.

Guha, R., Das, D., Grover, P., Guha, B. 1987, 'Germicidal activity of tar distillate obtained from pyrolysis of rice husk', Biological wastes .vol. 21, pp.93-100.

Gupta, AK., Muller, P. 1999, 'Pyrolysis of Paper and Cardboard in Inert and Oxidative Environments', J Propul Power, vol. 15, pp. 187-194.

Han, R., Zhao, C., Liu, J., Chen, A., Wang, H., 2015, 'Thermal characterization and syngas production from the pyrolysis of biophysical dried and traditional thermal dried sewage sludge', Bioresour Technol, vol. 198, pp.276-282.

Heo, HS. Et al. 2010, 'Fast pyrolysis of rice husk under different reaction conditions', Journal of Industrial and Engineering Chemistry, vol. 16, pp.27-31.

Homma, H., Homma, H., Idris, M. 2013, 'Wood Pyrolysis in Pre-Vacuum Chamber', Journal of Sustainable Bioenergy Systems. vol.3, pp.243.

Hu, S., Xiang, J., Sun, L., Xu, M., Qiu, J., Fu, P. 2008, 'Characterization of char from rapid pyrolysis of rice husk', Fuel Process Technol, vol. 89, pp.1096-1105. Isahak, WNRW., Hisham, MWM., Yarmo, MA., Yun Hin,T-y. 2012, 'A review on bio-oil production from biomass by using pyrolysis method Renewable and Sustainable', Energy Reviews, vol. 16, pp. 5910-5923.
Jahirul, M., Rasul, M., Chowdhury, A., Ashwath, N. 2012, 'Biofuels Production through Biomass Pyrolysis A Technological Review', Energies, vol. 5, pp.4952. Jain, A., Rao, TR., Sambi, S., Grover, P. 1994, 'Energy and chemicals from rice husk', Biomass Bioenergy, vol. 7, pp.285-289.

Ji-Lu, Z. 2007, 'Bio-oil from fast pyrolysis of rice husk: Yields and related properties and improvement of the pyrolysis system', J Anal Appl Pyrolysis, vol. 80, pp.3035.

Ji, LJ., Lu, SY., Yang, J., Du, CC., Chen, ZL., Buekens, A., Yan, JH. 2016, 'Municipal solid waste incineration in China and the issue of acidification a review', Waste Management \& Research, vol. 34, pp.280-297.

Jiang, J., Ma, X. 2011, 'Experimental research of microwave pyrolysis about paper mill sludge', Appl Therm Eng, vol. 31, pp.3897-3903.

Jin, L., Wang, L. 2015, 'Comparison of the Catalyzed Evaporation of Bio-oils From the Co-pyrolysis of Rice Husk and Waste Tires', Energ Source Part A. vol. 37, pp.2655-2661.

Jones, DA., Lelyveld, TP., Mavrofidis, SD., Kingman, SW., Miles, NJ. 2002, 'Microwave heating applications in environmental engineering-a review', Resources, Conservation and Recycling, vol. 34, pp.75-90.

Khor, K., Lim, K., Alimuddin, ZZ. 2010, 'Laboratoryscale pyrolysis of oil palm trunks', Energy Sources Part A: Recovery, Utilization, and Environmental Effects, vol. 32, pp.518-531.

Kim, M., Buonomo, E., Bonelli, P., Cukierman, A. 2010, 'The thermochemical processing of municipal solid wastes: Thermal events and the kinetics of pyrolysis', Energy Sources Part A: Recovery, Utilization, and Environmental Effects. vol. 32, pp.1207-1214.

Kim, SW. et al. 2013, 'Bio-oil from the pyrolysis of palm and Jatropha wastes in a fluidized bed', Fuel Process Technol, vol. 108, pp.118-124.

Kjeldsen, P., Barlaz, MA., Rooker, AP., Baun, A., Ledin, A., Christensen, TH. 2002, 'Present and long-term composition of MSW landfill leachate a review', Critical Reviews in Environmental Science and Technology, vol. 32, pp.297-336.

Kolokolova, O. Levi, T. Pang, S. Herrington, P. 2013, 'TORREFACTION AND PYROLYSIS OF BIOMASS WASTE IN CONTINUOUS REACTORS', Proceedings of the 13th International Conference on Environmental Science and Technology, Greece, 5-7 September

Krishna, BB., Singh, R., Bhaskar, T. 2015, 'Effect of catalyst contact on the pyrolysis of wheat straw and wheat husk', Fuel, vol. 160, pp.64-70.

Kunkes, EL., Simonetti, DA., West, RM., Serrano-Ruiz, JC., Gärtner, CA., Dumesic, JA., 2008, 'Catalytic conversion of biomass to monofunctional hydrocarbons and targeted liquid-fuel classes', Science, vol. 322, pp. 417-421. 
Lam, S.S., Chase, H.A, 2012, 'A review on waste to energy processes using microwave pyrolysis', Energies, vol. 5, pp.4209-4232.

Le Brech, Y., Jia, L., Cissé, S., Mauviel, G., Brosse, N., Dufour, A. 2015, 'Mechanisms of biomass pyrolysis studied by combining a fixed bed reactor with advanced gas analysis', J Anal Appl Pyrolysis, vol. 117, pp.334-346.

Lee, J.W., Hawkins, B., Day, D.M., Reicosky, D.C. 2010, 'Sustainability: the capacity of smokeless biomass pyrolysis for energy production, global carbon capture and sequestration', Energy \& environmental science, vol. 3, pp.1695-1705.

Lee, S., Kim, T.Y. 2015, 'Feasibility study of using wood pyrolysis oil-ethanol blended fuel with diesel pilot injection in a diesel engine', Fuel, vol. 162, pp.65-73.

Lee, Y.R., Choi, H.S., Park, H.C., Lee, J.E. 2015, 'A numerical study on biomass fast pyrolysis process: $A$ comparison between full lumped modeling and hybrid modeling combined with CFD', Computers \& Chemical Engineering, vol. 82, pp.202-215.

Lei, Z. et al. 2016, 'Pyrolysis of lignite following low temperature ionic liquid pretreatment', Fuel, vol.166, pp.124-129.

Li, H., Han, K., Wang, Q., Lu, C. 2015a, 'Pyrolysis of rice straw with ammonium dihydrogen phosphate: Properties and gaseous potassium release characteristics during combustion of the products', Bioresour Technol, vol.197, pp.193-200.

Li, L., Zhang, H., Zhuang, X. 2005, 'Pyrolysis of waste paper: characterization and composition of pyrolysis oil', Energy Sources, vol. 27, pp.867-873.

Li, R., Zhong, Z., Jin, B., Zheng, A. 2012, 'Application of mineral bed materials during fast pyrolysis of rice husk to improve water-soluble organics production', Bioresour Technol, vol. 119, pp.324-330.

Liu, K., Ma, X.Q., Xiao, H.M. 2010, 'Experimental and kinetic modeling of oxygen-enriched air combustion of paper mill sludge', Waste Manage Oxford, vol. 30, pp.1206-1211.

Liu, W.J., Tian, K., Jiang, H., Zhang, X.S., Yang, G.X. 2013, 'Preparation of liquid chemical feedstocks by co-pyrolysis of electronic waste and biomass without formation of polybrominated dibenzo-p-dioxins', Bioresour Technol, vol. 128, pp.1-7.

Lu, Q., Dong, C-q., Zhang, X-m., Tian, H-y., Yang, Y-p., Zhu, X-f. 2011, 'Selective fast pyrolysis of biomass impregnated with $\mathrm{ZnCl} 2$ to produce furfural: analytical Py-GC/MS study', J Anal Appl Pyrolysis, vol. 90, pp.204-212.

Lu, Q., Yang, X-I., Zhu, X-f. 2008, 'Analysis on chemical and physical properties of bio-oil pyrolyzed from rice husk', J Anal Appl Pyrolysis, vol. 82, pp.191-198.

Lu, Y. et al. 2012, 'Characterization of a bio-oil from pyrolysis of rice husk by detailed compositional analysis and structural investigation of lignin', Bioresour Technol, vol. 116, pp.114-119.

Luo, S.Y., Fu, J. 2015, 'Co-pyrolysis of biomass tar and iron ore fines for the production of direct reduced iron', J Renew Sustain Ener, vol. 7, 043131.

Maiti, S., Dey,S., Purakayastha, S., Ghosh, B. 2006, 'Physical and thermochemical characterization of rice husk char as a potential biomass energy source', Bioresour Technol, vol. 97, pp.2065-2070

Manyà, JJ.,García-Ceballos, F., Azuara, M. 2015, 'Pyrolysis and char reactivity of a poor-quality refusederived fuel (RDF) from municipal solid waste', Fuel Process Technol. vol. 140, pp.276-2070.

Margallo, M., Taddei MBM., Hernandez-Pellon, A., Aldaco, R. 2015,' Environmental sustainability assessment of the management of municipal solid waste incineration residues: a review of the current situation', Clean Technol Envir, vol. 17, pp.1333-1353. Martínez, JD., Puy N., Murillo R, García T, Navarro, MV. Mastral, A.M. 2013, 'Waste tyre pyrolysis - A review', Renewable and Sustainable Energy Reviews, vol. 23, pp.179-213.

Marttinen, S.K., Kettunen, R.H., Sormunen, K.M., Soimasuo, R.M., Rintala, J.A. 2002, 'Screening of physical-chemical methods for removal of organic material, nitrogen and toxicity from low strength landfill leachates', Chemosphere, vol. 46, pp.851-858. Meesuk, S., Cao, J-P., Sato, K., Ogawa, Y., Takarada, T. 2012, 'The effects of temperature on product yields and composition of bio-oils in hydropyrolysis of rice husk using nickel-loaded brown coal char catalyst', J Anal Appl Pyrolysis, vol. 94, pp. 238-245.

Melendi-Espina, S., Alvarez, R., Diez, M.A., Casal, M.D. 2015, 'Coal and plastic waste co-pyrolysis by thermal analysis-mass spectrometry', Fuel Process Technol, vol. 137, pp.351-358.

Méndez, A., Fidalgo, J.M., Guerrero, F., Gascó, G. 2009, 'Characterization and pyrolysis behaviour of different paper mill waste materials', J Anal Appl Pyrolysis vol. 86, pp.66-73.

Mendez, A., Paz-Ferreiro, J., Araujo, F., Gasco, G. 2014, 'Biochar from pyrolysis of deinking paper sludge and its use in the treatment of a nickel polluted soil. J Anal Appl Pyrolysis, vol.107, pp.46-52. Mohan, D., Pittman, C.U., Steele, P.H. 2006a, 'Pyrolysis of wood/biomass for bio-oil: a critical review', Energy \& fuels, vol. 20, pp.848-889.

Mohan, D., Pittman, C.U., Steele, P.H. 2006b, 'Pyrolysis of Wood/Biomass for Bio-oil: A Critical Review', Energ Fuel, vol. 20, pp.848-889.

Monte, MC., Fuente, E., Blanco, A., Negro, C. 2009, 'Waste management from pulp and paper production in the European Union', Waste Manage (Oxford), vol. 29, pp.293-308.

Montiano, MG., Diaz-Faes, E., Barriocanal, C. 2016,' Kinetics of co-pyrolysis of sawdust, coal and tar', Bioresour Technol, vol. 205, pp.222-229. 
Nurul Islam, M., Nurul Islam., Rafiqul Alam Beg, M., Rofiqul Islam, M. 2005,' Pyrolytic oil from fixed bed pyrolysis of municipal solid waste and its characterization, Renewable Energy, vol.30, pp.413420

Ohtsuka, Y., Zhiheng, W., Furimsky, E. 1997,' Effect of alkali and alkaline earth metals on nitrogen release during temperature programmed pyrolysis of coal', Fuel, vol. 76, pp.1361-1367.

Omar, H., Rohani, S. 2015, 'Treatment of landfill waste leachate and landfill gas: A review, Front Chem Sci Eng, vol. 9, pp.15-32.

Onal, E., Uzun, BB., Putun, AE. 2014, 'Bio-oil production via co-pyrolysis of almond shell as biomass and high density polyethylene', Energy Convers Manage, vol. 78, pp.704-710.

Oyedun, AO., Gebreegziabher, T,., Ng, DK., Hui, CW. 2014, 'Mixed-waste pyrolysis of biomass and plastics waste, A modelling approach to reduce energy usage', Energy, vol. 75, pp.704-710/

Paethanom, A., Yoshikawa, K. 2012, 'Influence of pyrolysis temperature on rice husk char characteristics and its tar adsorption capability', Energies, vol. 5, pp.704-710.

Paradela, F., Pinto, F., Ramos, AM., Gulyurtlu, I., Cabrita, I., 2009, 'Study of the slow batch pyrolysis of mixtures of plastics, tyres and forestry biomass wastes', J Anal Appl Pyrolysis, vol. 85, pp.392-398.

Park, J., Lee, Y., Ryu, C., Park, Y-K. 2014, 'Slow pyrolysis of rice straw: Analysis of products properties, carbon and energy yields', Bioresour Technol, vol. 155, pp.63-70.

Pattiya, A. 2011, 'Bio-oil production via fast pyrolysis of biomass residues from cassava plants in a fluidised-bed reactor', Bioresour Technol, vol. 102, pp.1959-1967.

Pels, JR., Kapteijn, F., Moulijn, JA., Zhu, Q., Thomas, KM. 1995, 'EVOLUTION OF NITROGEN FUNCTIONALITIES IN CARBONACEOUS MATERIALS DURING PYROLYSIS', Carbon, vol. 33, pp.1641-1653. Phan, AN., Ryu, C., Sharifi, VN., Swithenbank, J. 2008, 'Characterisation of slow pyrolysis products from segregated wastes for energy production, J Anal Appl Pyrolysis, vol. 81, pp.65-71.

Pinto, F., Paradela, F., Gulyurtlu, I., Ramos, AM. 2013, 'Prediction of liquid yields from the pyrolysis of waste mixtures using response surface methodology', Fuel Process Technol, vol. 116, pp.271-283.

Qian, Y., Zhang, J., Wang, J. 2014, 'Pressurized pyrolysis of rice husk in an inert gas sweeping fixedbed reactor with a focus on bio-oil deoxygenation', Bioresour Technol, vol. 174, pp.95-102.

Reckamp, J.M., Garrido, R.A., Satrio, J.A. 2014, 'Selective pyrolysis of paper mill sludge by using pretreatment processes to enhance the quality of bio-oil and biochar products', Biomass Bioenergy, vol. 71, pp.235-244.
Reichel, D., Siegl, S., Neubert, C., Krzack, S. 2015, 'Determination of pyrolysis behavior of brown coal in a pressurized drop tube reactor', Fuel, vol. 158, pp.983-998.

Ren. Q. et al. 2009, 'TG-FTIR study on co-pyrolysis of municipal solid waste with biomass' Bioresour Technol, vol. 100, pp.4054-4057.

Ridout, A.J., Carrier, M., Collard, F.X., Gorgens, J. 2016, 'Energy conversion assessment of vacuum, slow and fast pyrolysis processes for low and high ash paper waste sludge', Energy Convers Manage, vol. 111, pp.103-114.

Ridout, A.J., Carrier, M., Gorgens, J. 2015, 'Fast pyrolysis of low and high ash paper waste sludge: Influence of reactor temperature and pellet size', J Anal Appl Pyrolysis, vol.111, pp.64-75.

Rizkiana, J., Guan, G., Widayatno, W.B., Yang, J., Hao, X., Matsuoka, K., Abudula, A. 2016, 'Mg-modified ultra-stable $Y$ type zeolite for the rapid catalytic copyrolysis of low-rank coal and biomass', Rsc Adv, vol. 6, pp.2096-2105.

Ro KS, Hunt PG, Jackson MA, Compton DL, Yates SR, Cantrell K, Chang S 2014 Co-pyrolysis of swine manure with agricultural plastic waste: Laboratoryscale study Waste Manage Oxford 34:1520-1528

Roy, M.M., Dutta, A., Corscadden, K., Havard, P., Dickie, L. 2011, 'Review of biosolids management options and co-incineration of a biosolid-derived fuel', Waste Manage Oxford, vol. 31, pp.2228-223.5 Rushton, L. 2003. 'Health hazards and waste management', British medical bulletin, vol. 68, pp.183-197.

Sannita, E., Aliakbarian, B., Casazza, A.A., Perego, P., Busca, G. 2012, 'Medium-temperature conversion of biomass and wastes into liquid products, a review', Renewable and Sustainable Energy Reviews, vol. 16, pp.6455-6475.

Santos, R.M., Santos, A.O., Sussuchi, E.M., Nascimento, J.S., Lim,a Á.S., Freitas, L.S. 2015, 'Pyrolysis of mangaba seed: Production and characterization of bio-oil', Bioresour Technol, vol. 196, pp.43-48.

Sarkar, A., Chowdhury, R. 2014, 'Co-Pyrolysis of Paper Waste and Mustard Press Cake in a Semi-Batch Pyrolyser-Optimization and Bio-Oil Characterization', International Journal of Green Energy, vol. 13, no.4, pp.373-382.

Serrano-Ruiz, J.C., Dumesic, J.A. 2011, 'Catalytic routes for the conversion of biomass into liquid hydrocarbon transportation fuels', Energy \& Environmental Science, vol. 4, pp.83-99.

Shen, D., Jin, W., Hu, J., Xiao, R., Luo, K. 2015, 'An overview on fast pyrolysis of the main constituents in lignocellulosic biomass to valued-added chemicals: Structures, pathways and interactions', Renewable and Sustainable Energy Reviews, vol. 51, pp.761-774. 
Smets, K., Adriaensens, P., Reggers, G., Schreurs, S., Carleer, R., Yperman, J. 2011, 'Flash pyrolysis of rapeseed cake: influence of temperature on the yield and the characteristics of the pyrolysis liquid', J Anal Appl Pyrolysis, vol. 90, pp.118-125.

Stephanidis S, Nitsos C, Kalogiannis K, Iliopoulou E, Lappas A, Triantafyllidis K 2011 Catalytic upgrading of lignocellulosic biomass pyrolysis vapours: Effect of hydrothermal pre-treatment of biomass Catal Today 167:37-45

Strezov, V., Evans, T.J. 2009, 'Thermal processing of paper sludge and characterisation of its pyrolysis products', Waste Manage Oxford, vol. 29, pp.16441648.

Tang, C.Y., Zhang, D.X., Lu, X.L. 2015, 'Improving the Yield and Quality of Tar during Co-pyrolysis of Coal and Cotton Stalk', Bioresources, vol.10, pp.76677680 .

Thangalazhy-Gopakumar, S., Adhikari, S., Gupta, R.B., Tu, M., Taylor, S. 2011, 'Production of hydrocarbon fuels from biomass using catalytic pyrolysis under helium and hydrogen environments', Bioresour Technol, vol. 102, pp.6742-6749.

Tippayawong, N., Kinorn. J., Thavornun, S, 2008,' Yields and gaseous composition from slow pyrolysis of refuse-derived fuels', Energy Sources, Part A, vol. 30, pp.1572-1580.

Torri, IDV et al. 2016, 'Bio-oil production of softwood and hardwood forest industry residues through fast and intermediate pyrolysis and its chromatographic characterization', Bioresour Technol, vol. 200, pp.680-690.

Tyler, R.J. 1980, 'Flash pyrolysis of coals. Devolatilization of bituminous coals in a small fluidized-bed reactor', Fuel, vol.59, pp.218-226.

Uddin, M.N., Daud, W.W., Abbas, H.F. 2014, 'Effects of pyrolysis parameters on hydrogen formations from biomass: a review', Rsc Adv, vol.4, pp.10467-10490. Undri, A., Rosi, L., Frediani, M., Frediani, P. 2014b, 'Microwave assisted pyrolysis of corn derived plastic bags', J Anal Appl Pyrolysis, vol. 108, pp.86-97.

Uzun, B.B., Yaman, E. 2014, 'Thermogravimetric characteristics and kinetics of scrap tyre and Juglans regia shell co-pyrolysis', Waste Management \& Research, vol. 32, pp.961-970.

Uzunov, I., Uzunova, S., Angelova, D., Gigova, A. 2012, 'Effects of the pyrolysis process on the oil sorption capacity of rice husk', J Anal Appl Pyrolysis, vol. 98, pp.166-176.

Vamvuka, D., Kakaras, E., Kastanaki, E., Grammelis, P. 2003, 'Pyrolysis characteristics and kinetics of biomass residuals mixtures with lignite', Fuel, vol. 82, pp.1949-1960.

van Velzen, D., Langenkamp, H., Herb, G. 2002, 'Review: Mercury in waste incineration', Waste Management \& Research, vol. 20, pp.556-568.
Vispute, T.P., Zhang, H., Sanna, A., Xiao, R., Huber, G.W. 2010, 'Renewable chemical commodity feedstocks from integrated catalytic processing of pyrolysis oils', Science, vol. 330, pp.1222-1227.

Vrijheid, M. 2000, 'Health effects of residence near hazardous waste landfill sites: a review of epidemiologic literature', Environ Health Perspect, vol. 108, pp.101-112.

Wang, L. et al. 2011, 'Preparation of carbon black from rice husk by hydrolysis, carbonization and pyrolysis', Bioresour Technol, vol. 102, pp.8220-8224. Wang, X., Guo, H., Liu, F., Hu, R., Wang, M. 2016a,' Effects of CO 2 on sulfur removal and its release behavior during coal pyrolysis', Fuel, vol. 165, pp.484489.

Wang, X., Zhao, B.W., Yang, X.Y. 2016b, 'Co-pyrolysis of microalgae and sewage sludge: Biocrude assessment and char yield prediction', Energy Convers Manage, vol. 117, pp.326-334.

Wang, X.B., Deng, S.H., Tan, H.Z., Adeosun, A., Vujanovic, M., Yang, F.X., Duic, N, 2016c, 'Synergetic effect of sewage sludge and biomass co-pyrolysis: $A$ combined study in thermogravimetric analyzer and a fixed bed reactor', Energy Convers Manage, vol. 118, pp.399-405.

Wang, Z., Wang, F., Cao, J., Wang, J. 2010, 'Pyrolysis of pine wood in a slowly heating fixed-bed reactor: potassium carbonate versus calcium hydroxide as a catalyst', Fuel Process Technol, vol. 91, pp.942-950. White, J.E., Catallo, W.J., Legendre, B.L. 2011, 'Biomass pyrolysis kinetics: A comparative critical review with relevant agricultural residue case studies', J Anal Appl Pyrolysis, vol. 91, pp.1-33.

Whyte, H.E., Loubar, K., Awad, S., Tazerout, M. 2015, 'Pyrolytic oil production by catalytic pyrolysis of refuse-derived fuels: Investigation of low cost catalysts', Fuel Process Technol, vol. 140, pp.32-38.

Williams, P.T. 1990, 'A Review of Pollution from Waste Incineration', J Inst Water Env Man, vol. 4, pp.26-34.

Williams, P.T., Besler, S. 1993, 'The pyrolysis of rice husks in a thermogravimetric analyser and static batch reactor', Fuel, vol. 72, pp.151-159.

Williams, P.T., Nugranad, N. 2000, 'Comparison of products from the pyrolysis and catalytic pyrolysis of rice husks', Energy, vol. 25, pp.493-513.

Wiszniowski, J., Robert, D., Surmacz-Gorska, J., Miksch, K., Weber, J.V. 2006, 'Landfill leachate treatment methods: A review', Environmental Chemistry Letters, vol. 4, pp.51-61.

Worasuwannarak, N., Sonobe, T., Tanthapanichakoon, W. 2007, 'Pyrolysis behaviors of rice straw, rice husk, and corncob by TG-MS technique', J Anal Appl Pyrolysis, vol. 78, pp.265-271. $\mathrm{Wu}, \mathrm{C}$, et al. 2015a, 'CO 2 gasification of bio-char derived from conventional and microwave pyrolysis', Applied Energy, vol. 157, pp.533-539. 
Wu, C.H., Chang, C.Y., Lin, J.P. 1997, 'Pyrolysis kinetics of paper mixtures in municipal solid waste', $J$ Chem Technol Biotechnol, vol. 68, pp.65-74.

Wu, W., Mei, Y., Zhang, L., Liu, R., Cai, J. 2015b, 'Kinetics and reaction chemistry of pyrolysis and combustion of tobacco waste', Fuel, vol. 156, pp.7180.

Xie, Q. et al. 2015, 'Fast microwave-assisted catalytic co-pyrolysis of microalgae and scum for bio-oil production', Fuel, vol. 160, pp.577-582

Xue, Y., Zhou, S., Brown, R.C., Kelkar, A,. Bai, X. 2015, 'Fast pyrolysis of biomass and waste plastic in a fluidized bed reactor', Fuel, vol. 156, pp.40-46.

Yang, H., Yan, R., Liang, D.T., Chen, H., Zheng, C. 2006, 'Pyrolysis of palm oil wastes for biofuel production', As J Energy Env, vol. 7, pp.315-323.

Yang, X., Sun, L., Xiang, J., Hu, S., Su, S. 2013, 'Pyrolysis and dehalogenation of plastics from waste electrical and electronic equipment WEEE: A review', Waste Manage Oxford, vol. 33, pp.462-473.

Yao, W.K. et al. 2015, 'Thermally stable phosphorus and nickel modified ZSM-5 zeolites for catalytic copyrolysis of biomass and plastics', Rsc Adv, vol. 5, pp.30485-30494.

Yu F, Steele P, Ruan R 2010 Microwave pyrolysis of corn cob and characteristics of the pyrolytic chars Energy Sources, Part A: Recovery, Utilization, and Environmental Effects 32:475-484

Yu, Y.H., Kim, S.D., Lee, J.M., Lee, K.H. 2002, 'Kinetic studies of dehydration, pyrolysis and combustion of paper sludge', Energy, vol. 27, pp.457-469.

Zhai, M., Wang, X., Zhang, Y., Dong, P., Qi, G. 2015, 'Characteristics of rice husk tar pyrolysis by external flue gas', Int J Hydrogen Energy, vol. 40, pp.1078010787.

Zhang, B., Zhong, Z., Chen, P., Ruan, R. 2015a, 'Microwave-assisted catalytic fast pyrolysis of biomass for bio-oil production using chemical vapor deposition modified HZSM-5 catalyst', Bioresour Technol, vol. 197, pp.79-84.

Zhang, B., Zhong, ZP., Ding, K., Song, Z.W. 2015b, 'Production of aromatic hydrocarbons from catalytic co-pyrolysis of biomass and high density polyethylene: Analytical Py-GC/MS study' Fuel, vol. 139, pp.622-628.

Zhang, B., Zhong, ZP., Min, M., Ding, K., Xie, Q.L., Ruan, R. 2015c, 'Catalytic fast co-pyrolysis of biomass and food waste to produce aromatics: Analytical PyGC/MS study', Bioresour Technol, vol. 189, pp.30-35. Zhang, H.Y., Nie, JL., Xiao, R., Jin, BS., Dong, CQ., Xiao, GM. 2014, 'Catalytic Co-pyrolysis of Biomass and Different Plastics Polyethylene, Polypropylene, and Polystyrene To Improve Hydrocarbon Yield in a Fluidized-Bed Reactor', Energ Fuel, vol. 28, pp.19401947.

Zhang, QR, Zhang, SQ, Pan, TT 2011, 'Fraction Distribution Changes of Heavy Metals in Co-pyrolysis of Sewage Sludge and Corn Straw', Adv Mater ResSwitz, vol. 236-238, pp.187-191.

Zhang, S., Dong, Q., Zhang, L., Xiong, Y., Liu, X., Zhu, S, $2015 d$, 'Effects of water washing and torrefaction pretreatments on rice husk pyrolysis by microwave heating', Bioresour Technol vol. 193, pp.442-448.

Zhang, W.J., Yuan, CY., Xu, J., Yang, X. 2015e, 'Beneficial synergetic effect on gas production during co-pyrolysis of sewage sludge and biomass in a vacuum reactor', Bioresour Technol, vol. 183, pp.255258.

Zhang, Z. et al. 2015f, 'Low-temperature microwaveassisted pyrolysis of waste office paper and the application of bio-oil as an Al adhesive', Green Chemistry, vol.17, pp.260-270.

Zhang, Z.R., Macquarrie, D.J., Aguia,r PM, Clark, JH, Matharu, AS. 2015g, 'Simultaneous Recovery of Organic and Inorganic Content of Paper Deinking Residue through Low-Temperature MicrowaveAssisted Pyrolysis', Environmental Science \& Technology, vol. 49, pp.2398-2404.

Zheng, J-L., Kong, Y-P. 2010 'Spray combustion properties of fast pyrolysis bio-oil produced from rice husk', Energy Convers Manage, vol. 51, pp.182-18 
Joshi et al. 2018, European Journal of Sciences (EJS), vol. 1, no. 1, pp.10-25, DOI: 10.29198/ejs1802 